Biodiesels have their own problems and limitations like high viscosities which results in reduced atomization of fuel, lower volatility which causes oxidative polymerization during combustion which results in carbon ring sticking, higher gum deposition, injector choking, lubricating oil dilution, etc. and higher $\mathrm{NO}_{x}$ emissions [2].

In catalytic transesterification of oil in-which chemical reaction with alcohol produces biodiesel and also, yields alkyl based monoesters and bi-product glycerol [3]. Glycerol was used for the production of many useful pharmaceuticals and cosmetics. To promote biofuels in the transport sector new energy legislation has been passed in Europe that states that by $2020,10 \%$ of the energy used in transport purposes should be produced from biofuels. It will definitely escalate the production of glycerol compared to its demand in cosmetics and pharmaceutical products. So to utilize the whole production the new application areas of glycerol need to be found [4]. Solketal lowers gum formation, particulate emission, oxidation stability and improves cetane number \& cold flow properties. The fuel properties similar to ethanol makes solketal a promising alternative to ethanol [5].

\section{Structure of paper}

The section wise details of the manuscript are as follows:

\subsection{Introduction}

This section discuss the brief outline of reduction of fossil fuels and its effects on environment. The alternative resources for power generation and transport sector have been explained.

\subsection{Literature review}

This section deals with the holistic coverage of literature studies conducted by various researchers/academicians in the area of alternative fuels of petrol and diesel for power generation in different types of engines and evaluation of different emissions like $\mathrm{CO}, \mathrm{CO}_{2}$ and $\mathrm{NO}_{\mathrm{x}}$ etc. The findings of the researchers in the field of biofuels have also been discussed.

\subsection{Experiment \& methodology}

This section gives a clear insight to the research plan adopted for carrying out research work and explanation of experimental setup for the calculation of emission of $\mathrm{CO}, \mathrm{CO}_{2}$ and NOx of different fuels and fuel blends. Basic fuel properties have been displayed for the experimental setup.

SN Applied Sciences

\subsection{Results}

This section presents the results obtained after performing the different experiments on engine with different percentage of biofuel w.r.t engine speed. This section also represent the comparison of brake specific fuel consumption \& engine speed. The parameter used for comparing different fuels and fuel blends.

\subsection{Discussion}

In this section relevance of the research work has been discussed. Some important findings also explained about the biofuel used for experiment performed.

\subsection{Conclusion}

This section includes conclusions of the present research work conducted. This chapter also highlights all the key findings of the manuscript.

\section{Literature review}

Many researchers have been using ethanol, diesel and biodiesel blends with various compositions. Singh et al. noticed the efficiency of a blend of aqua \& ethanol, coconut oil, with a surfactant butan-1-ol (hybrid fuel) was found similar to diesel fuel with lower exhaust emissions except an increase in CO [6]. Consumption of fuel was higher because of the low gross calorific value of hybrid fuel and these fuel can be used directly in a Direct Injection (DI) Compression Ignition (Cl) engine without any changes or modifications in the existing engines. Jatropha Curcas oil (JCO) based hybrid micro-emulsion fuel containing pretreated JCO-1-Butanol-Ethanol was tested in a VCR DI Cl engine and slightly higher BSFC was observed as compared to pure diesel and comparable with other oxygenated fuels (JCOB100 and JCOB20) at all loads [2]. Yilmaz observed an increase in (Haydro carbon) $\mathrm{HC}$ and $\mathrm{CO}$ emissions and reduction in NOx emissions with the increase of ethanol percentage in the blend of ethanol \& diesel while the reverse happens with biodiesel methanol and diesel blend [7]. Lower BSFC noticed for Ethanol fuel in comparison to methanol fuel. The authors investigated the effect of hydrogen addition to $\mathrm{a} \mathrm{Cl}$ engine fueled with the diesel fuel-waste cooking oil biodiesel (WCOB) blend (B25) on the engine performance and exhaust emissions through experiment [8].

Armas et al. used $10 \%$ ethanol and $16 \%$ butanol blends and observed higher NOx and THC emissions with reduced 
$\mathrm{CO}$ and particulate matter (PM) emissions [9]. On comparison of biodiesel blend with $5 \%, 10 \%$ and $15 \%$ of methanol or ethanol with Euro $V$ diesel fuel and pure biodiesel, Zhu et al. found a reduction in NOX and PM emissions of a diesel engine for blended fuels [10]. Better results were observed for methanol blends. $5 \%$ blend could reduce the $\mathrm{CO}$ and $\mathrm{HC}$ with an improvement in brake thermal efficiency (BTE). With the increase in the proportion of alcohol in blends NOx and PM were decreased. Younus et al. investigated tyre pyrolysis oil and diesel blend with additives (Ethanol and Ethyl Hexyl Nitrate) and reported an increase in BTE in proportion to blend percentage ( $T 10, T 20, T 30)$ and a decrement in BSFC, CO, HC and NOx emissions than pure diesel [11]. The emission and performance characteristics of a diesel engine using Karanja oil/ Diesel as fuel by varying the proportion of Karanja oil from 10 to $100 \%$ in the blend and highest BSFC and exhaust gas temperature (EGT) for pure biodiesel at all loads were reported. Further, fewer $\mathrm{HC}$ emissions were observed for biodiesel as compared to diesel. Yasin et al. conducted experiments on biodiesel-ethanol-diesel blends (B20E5D75, B20E10D70, B20E15D65, B20E20D60) and reported higher BSFC of the blends in comparison to diesel and an overall reduction in the NOx emissions when higher ethanol concentration was used but increase in $\mathrm{CO}$ emission for all the blends [12]. Properties of castor oil biodiesel were studied by Berman et al. and concluded that this blend can be used as an alternative when blended with petrodiesel but the highest blending limit was $10 \%$ (of caster biodiesel) only because of very high ricinoleic acid [13]. Optimal operating parameters of the engine was analyzed by incrementing and decrementing the compression ratio upto CR18 and CR17 respectively to found the effect of jojoba biodieseldiesel bends on emission and performance phenomenon in the four stroke single cylinder compression ignition engine [14]. The authors performed the test on petro-diesel combustion engine to see the effects of a novel ternary blend of $n$-butanol and castor oil methyl ester (COME) and obtained optimum blending proportion which can simultaneously reduce UHC (Unburnt Hydro carbon), $\mathrm{CO}$ and NOx without affecting engine performance [15]. Kumar et al. observed a significant decrease in HC, \& CO emission with most types of biodiesel and no observation specifically to NOx emission was reported [16]. NOx emission increases with the decrease in chain length for saturated esters. Most highly unsaturated fuels: soybean and canola oil exhibit the highest NOx, poor oxidation stability, good cold flow properties and viscosity. In comparison to the diesel fuel, soybean oil \& palm oil and waste frying oil presented the lowest emissions [17]. B20 (20\% soybean biodiesel and $80 \%$ diesel fuel) blend offered lowest fuel consumption. For Biodiesel blend, 9\%, 10\%, 23\% reduction in $\mathrm{CO}, \mathrm{NOx}$ and $\mathrm{SO} 2$ emissions respectively with a $22 \%$ increase in $\mathrm{CO} 2$ emissions were reported. On testing of pure soybean oil, crude degummed soybean oil and soybean oil ethyl ester (SOEE) as a fuel in a diesel engine. A reduction of $21 \%$ in $\mathrm{HC}$ and $20 \%$ reduction in $\mathrm{PM}, 24 \%$ reduction in $\mathrm{CO}, 15 \%$ increase in NOx and $7 \%$ increase in fuel consumption, are witnessed by Osborne et al. in an engine fueled with biodiesel [18]. At the same injection timing, Kim et al. reported higher NOx and lower HC \& $\mathrm{CO}$ emissions for soybean biodiesel fuel in comparison to diesel [19]. Faster ignition, smaller particulate diameter and lower value of peak combustion pressure for soybean biodiesel were also reported. Low emissions have been reported when solketal is added up to $15 \%$.

Habibullah et al. investigated performance and emissions characteristics in diesel engine with the use of palm or coconut biodiesel blend and their different combination namely PB20, CB20, PB5CB15, PB10CB10 and PB15CB5 as different fuels [20]. In comparison to diesel, these blends produced higher BSFC (3.24\% to 4.07\%) and lower engine brake power ( $0.6 \%$ to $1.72 \%)$. NOx emissions increased from $1.79 \%$ to $4.49 \%$ for all the biodiesel blends into consideration. The reason was high combustion temperature and presence of fuel-borne oxygen in the blends. The HC and $\mathrm{CO}$ and emission were also reduced by $13.54-23.79 \%$ and $3.36-7.01 \%$ respectively. In this work, the effect of 1-Hexanol on engine parameters has been studied to improve the combustion, performance and emission characteristics of $\mathrm{Cl}$ engine to know the best possible injection time [21]. Jayaraman et al. prepared blend without liquid additives showing better performance along with $6 \%$ of DEE blended fuel [22].

Hosseini et al. evaluated the effects of the addition of 30,60 and $90 \mathrm{ppm}$ of alumina $\left(\mathrm{Al}_{2} \mathrm{O}_{3}\right)$ nano-particles to $5 \%$ and $10 \%$ biodiesel from waste cooking oil (B5 and B10 blends) on a single-cylinder $\mathrm{Cl}$ engine [23]. Optimized performance and exhaust emission seem to be produced by B10AL90 blend. In general, the addition of catalyst increase the power (5.36\%), torque, NOx (43.61\%), EGT $(5.80 \%)$ and reduces the $\mathrm{CO}(2.94 \%)$ \& UBHC emissions (20.56\%) and specific fuel consumption (14.66\%) as compared to diesel fuel.

Celik and Ozgoren found $45.77 \%$ increased $\mathrm{CO} 2$ emissions, $48.88 \%$ decreased in $\mathrm{CO}$ emissions, $46.03 \%$ decreased smoke emissions, besides a very high increasing rate of NOx in the blend of soybean oil (15\%) and hazelnut methyl Ester (15\%) with diesel fuel (70\%) as compared to diesel [24]. Soybean crude Oil-based biodiesel prepared by alkaline catalyzed transesterification was studied by Qi et al. [25]. A higher viscosity and flashpoint for biodiesel than that of pure diesel were observed especially at low temperatures. Owing to shorter injection delay combustion for biodiesel starts earlier at all engine loads. Higher BSFC of biodiesel was noticed in comparison to diesel. 
Under full load speed characteristics, the emission of NOx, $\mathrm{CO}, \mathrm{HC}$ and smoke were decreased by $5 \%, 27 \%, 27 \%$ and $52 \%$ respectively. Authors [26] investigated that while using biodiesel in addition to $\mathrm{Al} 2 \mathrm{O} 3$ in different concentrations such as 25,50 and $100 \mathrm{ppm}$ and found that while using $25 \mathrm{ppm}$ is suitable for low emissions and better brake thermal efficiency in a diesel engine.

Though a large number and growing literature were available on different biodiesel and their blends yet comparatively very less work was reported on solketal-diesel blends.

\section{Experiment and methodology}

In this study, different blends of soybean biodiesel with solketal are used. Test fuels are diesel (D), soybean biodiesel (SB), SBS9 (9\%S, 91\%SB), SBS10 (10\%S, 90\%SB), SBS12 (12\%S, 88\%SB), SBS15 (15\%S, 85\%SB). All tested are conducted on three different engine RPM $(1200,1500$ and 2000) and at 50\% load. The basic fuel properties of diesel fuel, soybean biodiesel and solketal are tabulated in Table 1. No modification on the diesel engine for the tests was made. The results are averaged for four times repetition engine tests.

A single-cylinder, 4-stroke, multi-fuel, water-cooled research engine manufactured by Kirloskar Oil Engines, having $87.5 \mathrm{~mm}$ bore, $110 \mathrm{~mm}$ stroke, 661 cc capacity, 3.5 kW @ 1500 RPM rated power for diesel and compression ratio range from 12:1 to 17:1 with injection variation is used for experiments. A water-cooled eddy current type dynamometer with a loading unit is provided for loading of the crankshaft. The loading unit consists of a strain gauge type load cell with range $(0-50 \mathrm{~kg})$ and a $230 \mathrm{~V} \mathrm{AC}$ digital load indicator of range $(0-50 \mathrm{~kg})$. The fuel measuring unit, manometer, transmitters for air and fuel flow measurements, process indicators and engine indicator is installed as standard fittings of setup. Two rotameters and a calorimeter are provided for cooling and

Table 1 Basic fuel properties of test fuels

\begin{tabular}{lllll}
\hline Fuel & $\begin{array}{l}\text { Density } \\
\left(15{ }^{\circ} \mathrm{C}, \mathrm{kg}\right. \\
\left.\mathrm{m}^{-3}\right)\end{array}$ & $\begin{array}{l}\text { Viscos- } \\
\text { ity }\left(40^{\circ} \mathrm{C},\right. \\
\left.\mathrm{mm}^{2} \mathrm{~s}^{-1}\right)\end{array}$ & $\begin{array}{l}\text { Higher } \\
\text { Heating } \\
\text { Value(MJ kg } \\
-1)\end{array}$ & $\begin{array}{l}\text { Flash } \\
\text { point }\left({ }^{\circ} \mathrm{C}\right)\end{array}$ \\
\hline D & 831.7 & 2.58 & 45.98 & 63 \\
SB & 919.7 & 5.06 & 39.10 & 140 \\
SOLKETAL & 1071.1 & 5.21 & 25.91 & 84 \\
SBS9 & 919 & 4.42 & 41 & 88 \\
SBS10 & 919.43 & 4.43 & 40.43 & 89.4 \\
SBS12 & 921 & 4.47 & 39.31 & 91.1 \\
SBS15 & 923 & 4.52 & 37.32 & 92 \\
\hline
\end{tabular}

flow measurements of water respectively. All the data is analyzed by "Engine soft", an engine performance analysis software. The exhaust gases namely $\mathrm{CO}, \mathrm{THC}, \mathrm{CO} 2$ and NOx are analyzed by AVL gas analyzer. The image of the experimental setup image is shown in Fig. 1.

\section{Results}

Figure 2 represents the comparison of brake specific fuel consumption \& engine speed. The parameter used for comparing different fuels and fuel blends was Brake Specific Fuel Consumption (BSFC). Figure shows that as the BSFC increases with the engine speed. Different colour bar shows different types of blend and their variation with respect to BSFC and engine speed. SBS represents soybean biodiesel and solketel.

The variation of $\mathrm{CO}$ emission at various values of engine speed for diesel, soybean and all other four blends have been presented in Fig. 3. It can be observed from figure that the CO emission is highest in case of diesel, so it is not a good option as fuel. But with different blends of solketal, $\mathrm{CO}$ emission reduced upto the half of emission as compared to the diesel.

The comparison of $\mathrm{CO}_{2}$ emissions with engine speed for different fuels were shown in Fig. 4. $\mathrm{CO}_{2}$ emission is the main exhaust emissions and not responsible to the air pollution however it is a major greenhouse gas. The $\mathrm{CO}_{2}$ emission decreases with increase in engine speed. But it is minimum for diesel fuel as compared to the other blends of fuel for all engine speeds.

Figure 5 represents the variation of $\mathrm{NO}_{x}$ emission with the engine speed. $\mathrm{NO}_{\mathrm{x}}$ emission are unwanted emissions and the main reason for this emission is oxygen in air. Unlike to previous figures, $\mathrm{NO}_{\mathrm{x}}$ emission increases for

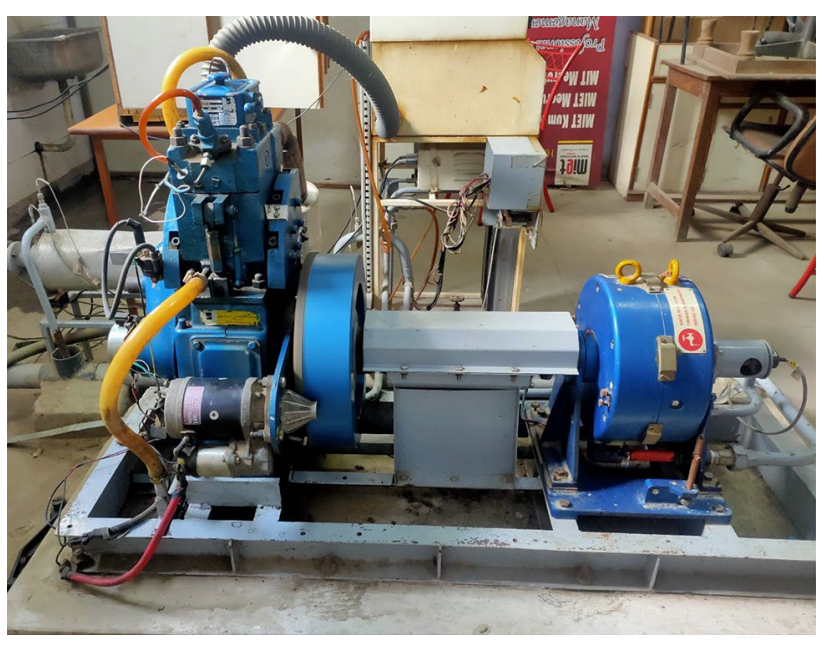

Fig. 1 Experimental setup 
Fig. 2 Comparison of brake specific fuel consumption \& engine speed

Fig. 3 Comparison of $\mathrm{CO}$ emissions with engine speed

Fig. 4 Comparison of $\mathrm{CO}_{2}$ emissions with engine speed
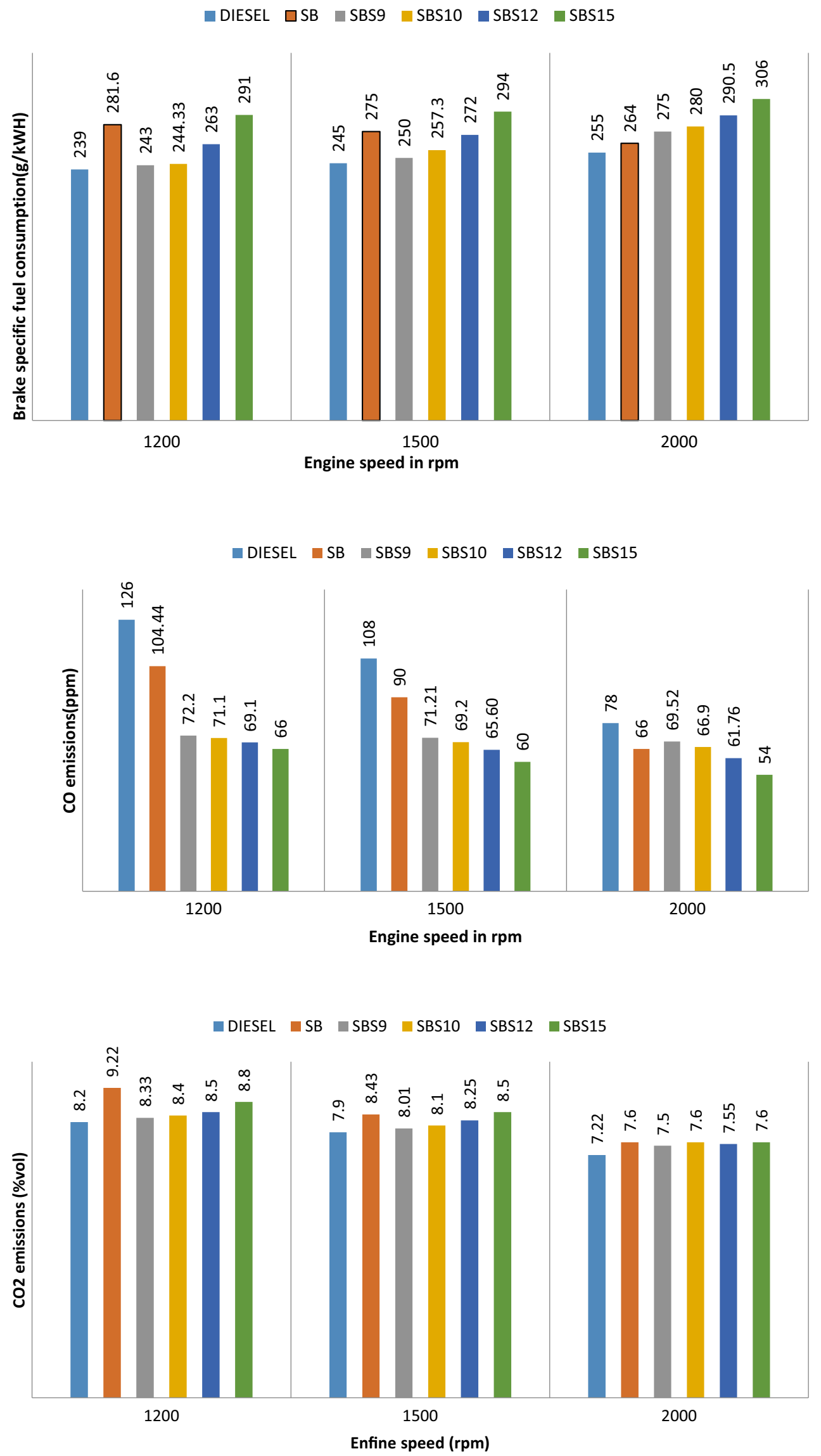

SN Applied Sciences 
Fig. 5 Comparison of $\mathrm{NO}_{\mathrm{x}}$ emissions with engine speed $\square$ DIESEL $\square$ SB $\square$ SBS9 $\quad$ SBS10 $\square$ SBS12 $\backsim$ SBS15

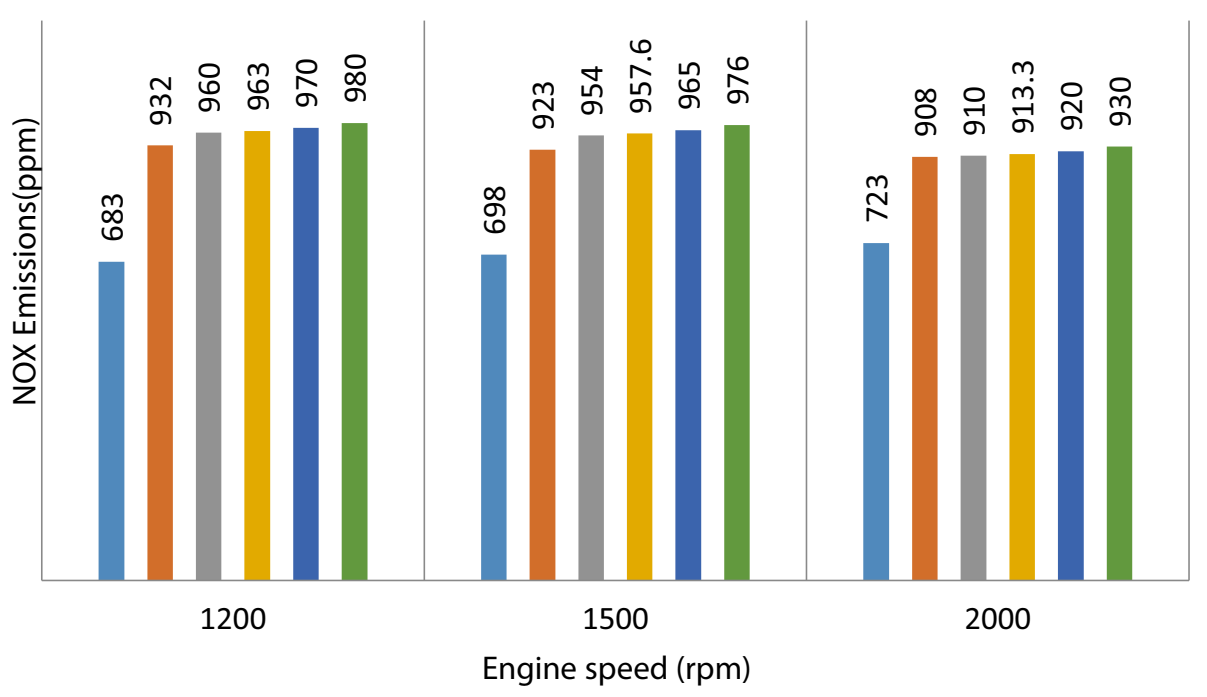

biodiesel with solketal and its blends as compared to the diesel. But for all other fuels, it decreases for higher value of engine speed.

The comparison of hydrocarbon emission with engine speed has been shown in Fig. 6. The ain reason of the hydrocarbon emissions is incomplete combustion. It is clear from figure that the rate of hydrocarbon emission is the highest for diesel and were not significantly affected by the engine speed.

\section{Discussion}

Solketal and soyabean biodiesel blends have higher flash points which are helpful in the proper handling of the fuels. Also, it has been observed that fuel consumption is higher for all the blends due to an increase in density and viscosity. BSFC is one of the important criterion for comparing different fuels and fuel blends used in engines. Results indicated that BSFC values for blends increases as the engine speed increases. Owing to more density of biodiesel blends than diesel, it also found that higher BSFC values for biodiesel and its various blends with solketal than that of pure diesel. On addition of solketal to biodiesel, BSFC values for different blends increases
Fig. 6 Comparison of THC emissions with engine speed $\square$ DIESEL $\square$ SB $\square$ SBS9 $\quad$ SBS10 $\square$ SBS12

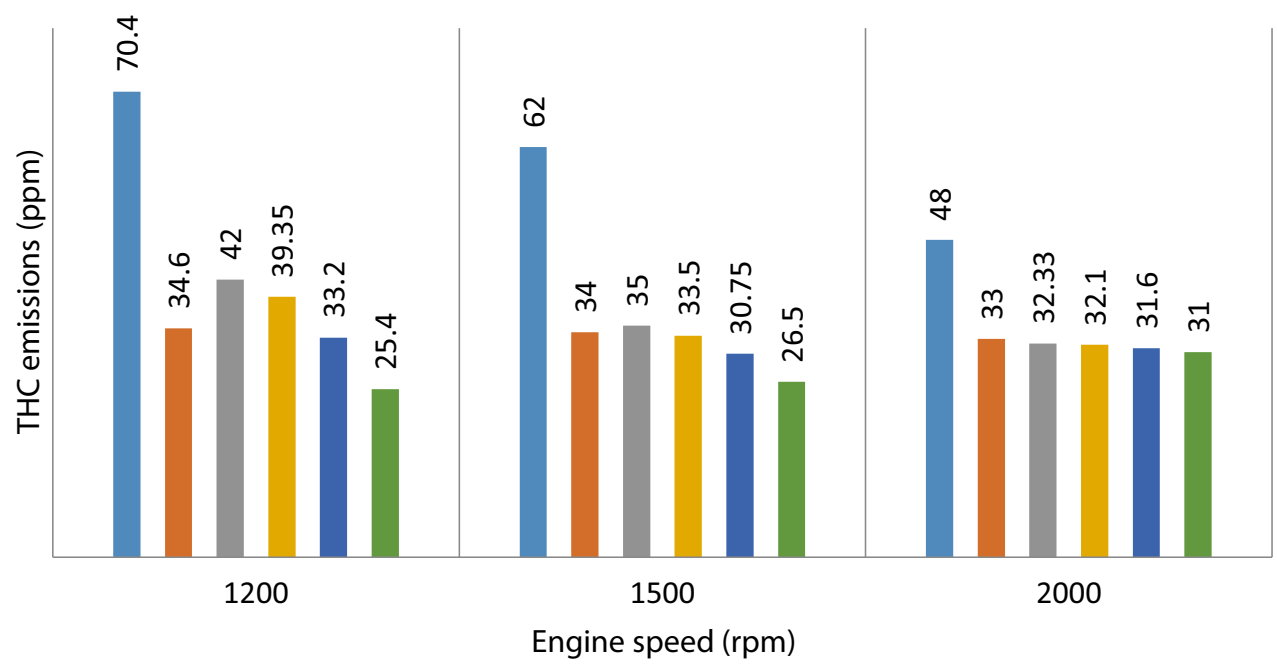


with the increase of proportion solketal in the blends and being highest for SBS15 blend at all engine speeds. A calibrated AVL gas analyzer was used for measuring of total hydro-carbons (THC), oxides of nitrogen (NO) ${ }_{x}$ carbon monoxides $(\mathrm{CO})$, carbon dioxide $\left(\mathrm{CO}_{2}\right)$ emissions. After performing the experiments, it was found that the $\mathrm{CO}$ emission is lower for soybean and other various solketal and biodiesel blends as compare to the diesel. This is due to the presence of solketal in fuel which in turn increases the oxygen level in fuel. Therefore, as the percentage of solketal in blend increases, the $\mathrm{CO}$ emission will get lowered. $\mathrm{CO}$ emission is also depends on the engine speed. As $\mathrm{CO}$ emission reduces with the increase in engine speed for diesel, soybean and all other four blends used in the study. The lowest $\mathrm{CO}$ emissions were reported by SBS15 blend at 2000 RPM. SBS15 blend showed approximately $47 \%$ lower $\mathrm{CO}$ emissions than diesel at $1200 \mathrm{RPM}$.

As $\mathrm{CO}_{2}$ is one of the major greenhouse gases and it's been noted that $\mathrm{CO}_{2}$ emissions decrease with the increase of engine speed at constant load. The value of $\mathrm{CO}_{2}$ emission for biodiesel and solketal \& its blends is higher than that of diesel at various engine speeds. The highest value of $\mathrm{CO}_{2}$ emission for SBS15 blend is achieved at 1200 RPM. On the other hand, lower $\mathrm{CO}_{2}$ emission is for pure biodiesel at all engine speeds. NOx emission was directly affected by combustion temperature, residual nitrogen in the air and the oxygen content in the fuel. Higher NOx emissions have been found for biodiesel and its blends with solketal in comparison to the diesel. NOx emissions increase with the rise of solketal percentage in the blend and decreases with increasing the engine speed. NOx emissions are approximately the same for all solketal and soybean biodiesel blends. Hydrocarbons are produced due to incomplete combustion of hydrocarbon fuels. It was found that THC emissions for biodiesel and biodiesel blends with solketal are much lower than that of pure diesel. THC emissions also reduces with increasing the percentage of solketal in blend being lowest for SBS15 blend. THC emissions reduce up to $63 \%$ using SBS15 blend in the engine at 1200 RPM. A significant reduction in THC is produced by using solketal as a fuel additive with biodiesel.

\section{Conclusion}

A comprehensive experimental study has been carried out on BSFC and exhaust emissions of solketal biodiesel. Characterization of test fuels results that solketal addition to biodiesel increases flash point which helps in the proper handling of fuel. Emission results conclude that $\mathrm{CO}$ and THC emissions were lower for biodiesel and various solketal blends. These emissions were reduces with the engine speed and percentage of solketal in the blend.
All the blends and biodiesel showed higher NOx and $\mathrm{CO} 2$ emissions at all engine speeds and increases with an increase in solketal percentage. BSFC for all four blends come out to be higher than diesel. It can also be concluded that solketal can be utilized as a fuel additive with biodiesel in a diesel engine without any alteration in the engine. Fuel additive may be the possible avenue for the utilization of solketel.

Further research work related to combustion characteristics, injection timing and exhaust emissions is the need of time to be carried out at different engines at different load conditions at different engines and with different biodiesel and solketel blends as indicated by the present study. A very few studies on solketal-gasoline fuel blends in the spark-ignition engine are observed and the need for more such studies is felt.

\section{Compliance with Ethical Standards}

Conflict of interest The authors declare that they have no conflict of interest.

Open Access This article is licensed under a Creative Commons Attribution 4.0 International License, which permits use, sharing, adaptation, distribution and reproduction in any medium or format, as long as you give appropriate credit to the original author(s) and the source, provide a link to the Creative Commons licence, and indicate if changes were made. The images or other third party material in this article are included in the article's Creative Commons licence, unless indicated otherwise in a credit line to the material. If material is not included in the article's Creative Commons licence and your intended use is not permitted by statutory regulation or exceeds the permitted use, you will need to obtain permission directly from the copyright holder. To view a copy of this licence, visit http://creativecommons .org/licenses/by/4.0/.

\section{References}

1. Imtenan S, Masjuki HH, Varman M, Arbab MI, Sajjad H, FattahHasib IRASM (2014) Emission and performance improvement analysis of biodiesel-diesel blends with additives. Procedia Engineering 90:472-477. https://doi.org/10.1016/j.proeng.2014.11.759

2. Kumar H, Konwar LJ, Aslam M, Sarma AK (2016) Performance, combustion and emission characteristics of a direct injection VCR Cl engine using a Jatropha curcas oil microemulsion: a comparative assessment with JCO B100, JCO B20 and petrodiesel. RSC advances 6(44):37646-37655. https://doi.org/10.1039/ C6RA04795E

3. Kanitkar A, Balasubramanian S, Lima M, Boldor D (2011) A critical comparison of methyl and ethyl esters production from soybean and rice bran oil in the presence of microwaves. Biores Technol 102(17):7896-7902. https://doi.org/10.1016/j.biort ech.2011.05.091

4. Vicente G, Melero JA, Morales G, Paniagua M, Martín E (2010) Acetalisation of bio-glycerol with acetone to produce solketal over sulfonic mesostructured silicas. Green Chem 12(5):899907. https://doi.org/10.1039/b923681c 
5. Mota CJ, da Silva CX, Rosenbach N Jr, Costa J, da Silva F (2010) Glycerin derivatives as fuel additives: the addition of glycerol/ acetone ketal (solketal) in gasolines. Energy Fuels 24(4):27332736. https://doi.org/10.1021/ef9015735

6. Singh PJ, Khurma J, Singh A (2010) Preparation, characterisation, engine performance and emission characteristics of coconut oil based hybrid fuels. Renewable Energy 35(9):2065-2070. https:// doi.org/10.1016/j.renene.2010.02.007

7. Yilmaz N (2012) Comparative analysis of biodiesel-ethanol-diesel and biodiesel-methanol-diesel blends in a diesel engine. Energy 40(1):210-213. https://doi.org/10.1016/j.energ y.2012.01.079

8. Akcay M, Yilmaz IT, Feyzioglu A (2020) Effect of hydrogen addition on performance and emission characteristics of a commonrail $\mathrm{Cl}$ engine fueled with diesel/waste cooking oil biodiesel blends. Energy 212:118538. https://doi.org/10.1016/j.energ y.2020.118538

9. Armas O, García-Contreras R, Ramos Á (2014) Pollutant emissions from New European Driving Cycle with ethanol and butanol diesel blends. Fuel Process Technol 122:64-71. https:// doi.org/10.1016/j.fuproc.2014.01.023

10. Zhu L, Cheung CS, Zhang WG, Huang Z (2010) Emissions characteristics of a diesel engine operating on biodiesel and biodiesel blended with ethanol and methanol. Sci Total Environ 408(4):914-921. https://doi.org/10.1016/j.scitotenv.2009.10.078

11. Younus SM, Kumar R, Rao DYH (2013) Performance and Emissions Characteristics of Diesel Engine Fueled With Tyre Pyrolysis Oil \& Diesel Blends with Additives. International Journal of Engineering Science Invention 2(5):32-37

12. Mat Yasin MH, Mamat R, Leman AM, Khalid A, Tamaldin N (2014) Experimental Investigation on Biodiesel-Ethanol-Diesel Blends Operating with a Diesel Engine. Applied Mechanics and Materials. 465:221-225. https://doi.org/10.4028/www.scientific.net/ AMM.465-466.221

13. Berman P, Nizri S, Wiesman Z (2011) Castor oil biodiesel and its blends as alternative fuel. Biomass Bioenerg 35(7):2861-2866. https://doi.org/10.1016/j.biombioe.2011.03.024

14. Hariram, V., Solomon, G.R., Raj, D.S., Dev, M.J., Kumar, U.N., Gokulakesavan, M., Premkumar, T.M. and Seralathan, S (2020) Impact of compression ratio in the emission and performance phenomenon of a $\mathrm{Cl}$ engine fuelled with jojoba biodiesel blends. Materials Today: Proceedings. https://doi.org/10.1016/j. matpr.2020.05.439

15. Thakkar K, Kuchhwaha SS, Kodgire P, Srinivasan S (2020) Combustion investigation of ternary blend mixture of biodiesel/nbutanol/diesel: $\mathrm{Cl}$ engine performance and emission control. Renewable and Sustainable Energy Reviews, In press. https:// doi.org/10.1016/j.rser.2020.110468

16. Kumar N, Chauhan SR (2013) Performance and emission characteristics of biodiesel from different origins: A review. Renew Sustain Energy Rev 21:633-658. https://doi.org/10.1016/j. rser.2013.01.006
17. D'Silva MAV, Ferreira BLG, da Costa Marques LG, Murta ALS, de Freitas MAV (2017) Comparative study of NOx emissions of biodiesel-diesel blends from soybean, palm and waste frying oils using methyl and ethyl transesterification routes. Fuel 194:144-156. https://doi.org/10.1016/j.fuel.2016.12.084

18. Osborne D, Fritz S, Glenn D (2011) The effects of biodiesel fuel blends on exhaust emissions from a general electric tier 2 line-haul locomotive. J Eng Gas Turbines Power. https://doi. org/10.1115/1.4002916

19. Kim MY, Yoon SH, Hwang JW, Lee CS (2008) Characteristics of particulate emissions of compression ignition engine fueled with biodiesel derived from soybean. J Eng Gas Turbines Power. https://doi.org/10.1115/1.2906215

20. Habibullah M, Rizwanul Fattah IM, Masjuki HH, Kalam MA (2015) Effects of palm-coconut biodiesel blends on the performance and emission of a single-cylinder diesel engine. Energy Fuels 29(2):734-743. https://doi.org/10.1021/ef502495n

21. Santhosh K, Kumar GN (2021) Effect of injection time on combustion, performance and emission characteristics of direct injection $\mathrm{Cl}$ engine fuelled with equi-volume of 1-hexanol/diesel blends. Energy 214:118984. https://doi.org/10.1016/j.energ y.2020.118984

22. Jayaraman, J., Basha, S.M.M., Anil, P.P.S.V., Mariadhas, A., Joy, N. and Appavu, P., (2020). Influence of liquid additives on waste cooking oil biodiesel-isopropanol blend operated in $\mathrm{Cl}$ engine. Materials Today: Proceedings. https://doi.org/10.1016/j. matpr.2020.09.489

23. Hosseini SH, Taghizadeh-Alisaraei A, Ghobadian B, Abbaszadeh-Mayvan A (2017) Effect of added alumina as nano-catalyst to diesel-biodiesel blends on performance and emission characteristics of $\mathrm{Cl}$ engine. Energy 124:543-552. https://doi. org/10.1016/j.energy.2017.02.109

24. Çelik M, Özgören YÖ (2017) The determination of effects of soybean and hazelnut methyl ester addition to the diesel fuel on the engine performance and exhaust emissions. Appl Therm Eng 124:124-135. https://doi.org/10.1016/j.appltherma leng.2017.06.008

25. Qi DH, Geng LM, Chen H, Bian YZ, Liu J, Ren XC (2009) Combustion and performance evaluation of a diesel engine fueled with biodiesel produced from soybean crude oil. Renewable Energy 34(12):2706-2713. https://doi.org/10.1016/j.renene.2009.05.004

26. Edam MS, Al-Dawody, M. F. (2019) Effect of Nano Fuel Additives on the Characteristics of Diesel Engine Fed with Biodiesel Blended Fuel. Journal of University of Babylon for Engineering Sciences. 15:124-141

Publisher's Note Springer Nature remains neutral with regard to jurisdictional claims in published maps and institutional affiliations. 